\title{
Synergistic Effect of Yeast and Cisplatin against Induced Skeletal Muscle Carcinoma in Mice: Histological Study
}

\author{
Original \\ Article \\ Hekmat A. Ahmed Sorour, Eman Said Mahmoud, Shimaa Zakaria Elshora \\ Histology Department, Faculty of Medicine for Girls, Al Azher University, Egypt
}

\begin{abstract}
Background: Cisplatin is widely used for cancer treatment. Cisplatin induces cytotoxicity for cancer cells and normal cells. Yeast as an alternative cancer therapy may have less side effects.

Aim of the Study: To estimate the synergistic efficacy of Yeast and Cisplatin against carcinoma mass induced on the skeletal muscle of adult male albino mice through detection of the histological changes in the skeletal muscle.

Material and Methods: Fifty male albino mice, were divided into five equal groups. GI; Control group. The rest of animals were inoculated intramuscularly with $0.2 \mathrm{ml}$ Ehrlich ascites carcinoma cells in the right thigh at day 1 . A solid mass appeared on the 10th day. These animals were divided into four groups: G II; The untreated group. G III; Treated with Cisplatin (3 mg/ $\mathrm{kg}$ /week) intra peritoneally. G IV; Were injected IM with $1 \mathrm{ml}$ of Heat-killed non-pathogenic yeast suspension 1 x $10^{7}$ cells/ $\mathrm{ml}$, 3times /week .G V; Injected by Yeast and Cisplatin in the same previous doses. All therapies were given from the11thday until day $35^{\text {th }}$. Histological studies were done using H\&E stain, Masson's trichrome stain and BCL2immunohistochemical reaction. Morphometric and statistical studies were performed.

Results: Muscle fibers in GII appeared thinner, deformed, widely separated and infiltrated by leucocytes. Compact sheets of tumor cells showed pleomorphism and numbers of abnormal mitotic figures. Muscle fibers of GIII were fragmented, widely separated and developed signs of necrosis but tumor cells were less numerous. Considerable inflammatory reaction was also noticed. GIV and GV showed improvement in the histological pictures of muscle fibers. The tumor cells were relatively less than those of GII. The muscle fibers partially regained their normal appearance.

Conclusion: Heat-killed non-pathogenic yeast enhanced the cytotoxic activity of Cisplatin and potentiate the benefit of using a combination of low-dose Cisplatin and heat-killed non-pathogenic yeast in treatment of cancer.
\end{abstract}

Received: 02 July 2019, Accepted: 14 July 2019

Key Words: Cisplatin, ehrlich ascitescarcinoma, skeletal muscle, yeast (s. cerevisiae).

Corresponding Author: Shimaa Zakaria Elshora, MSc, Histology Department, Faculty of Medicine for Girls, Al Azher University, Egypt, Tel.: +20 40 3350169, E-mail: elshorashimaa82@yahoo.com

ISSN: $1110-0559$, Vol. 43, No. 1

\section{INTRODUCTION}

Cancer is one of the leading causes of death all-over the world.EAC is one of the commonest experimental tumors. EAC is an undifferentiated carcinoma that is initially hyperdiploid, does not have tumor-specific transplantation antigen, has high transplantable capability, has noregression, has short life span, has rapid proliferation and $100 \%$ malignancy ${ }^{[1]}$. Intra muscular injection of Ehrlich tumor cells induces a solid tumor of nearly $1 \mathrm{~cm}$ in diameter ${ }^{[2]}$.

Ehrlich ascites carcinoma similar to human tumors which are sensitive to chemotherapy because they are undifferentiated and have a rapid growth rate. The best drug being ineffective or minimally effective for normal cells have been paying attention. Usage of natural sources as an alternative cancer therapy is considered to have a great value for cancer control. EAC was chosen in the present experiment because they are rapidly growing experimental tumor model where various experimental designs for anticancer agents can be applied ${ }^{[3,4]}$.

Cisplatin is one of the most common chemotherapeutic drugs widely used for cancer treatment. Cisplatin damages tumors through different pathways: Activation of signal transduction pathways including death receptor signaling, calcium signaling, activation of mitochondria. Also through induction of apoptosis. Both apoptosis and cytotoxicity affect not only cancer cells, but also normal cells. Therefore, Cisplatin may lead to diverse side-effects such as neuro-, renal-toxicity and/or bone marrow-suppression ${ }^{[5,6]}$.

Saccharomyces Cerevisiae (SC) is one of the most famous forms of yeast known more commonly as baker's or brewer's yeast which may be utilized as food. They contain most of the B-complex vitamins, with the exception of vitamin B-12 and a good concentration of protein. While 
yeast is widely used as dietary supplements in countries whose diets are protein deficient, they are considered as immune protection in well-developed countries ${ }^{[7,8]}$. Also, beta glucans are one of the most plentiful forms of polysaccharides located in the cell wall of yeast that have been used as adjuvant therapy for cancer treatment in clinical trials, with a positive effect on the quality of life and patients' survival ${ }^{[9]}$.

\section{AIM OF THE WORK}

To estimate the synergistic efficacy of Yeast and Cisplatin against carcinoma mass induced in the skeletal muscle of adult male albino mice through detection of the histological changes in the skeletal muscle.

\section{MATERIALS AND METHODS}

\section{A-Drugs and chemicals}

\section{1-Cisplatin}

Cisplatin used in the present study was purchased from El-Ezaby pharmacy. Cisplatin low dose $3 \mathrm{mg} / \mathrm{kg}$ body weight was given as an intraperitoneal(IP) injection ${ }^{[10]}$.

\section{2- Saccharomyces Cerevisiae (SC)}

Yeast suspensions were washed once with phosphatebuffered saline (PBS) and incubated for one hour at 90C0 to kill yeast. Following washing, yeast cells were quantified using a hemocytometer and cell suspensions were adjusted at $1 \times 10^{7}$ cells $/ \mathrm{ml}$ and injected intramuscularly (IM) at the site of the tumor 3 times per week ${ }^{[11]}$.

\section{3- Ehrlich ascites carcinoma cells (EAC)}

The Ehrlich Ascites Carcinoma cells (EAC) were obtained from National Cancer Institute (Cairo, Egypt) and maintained in our laboratory to be given to mice by weekly I.P. transplantation of $2.5 \times 10^{6}$ cells/mouse. Ascites fluid was collected on the $7^{\text {th }}$ day after injection. The Ehrlich cells were washed twice and then suspended in $5 \mathrm{ml}$ saline then the forty mice were inoculated intramuscularly with $0.2 \mathrm{ml}$ of the previous suspension in gastrocenemius muscle of the right thigh of the lower limb of each mouse at day 1 . On the 10thday post-tumor cell inoculation, mice were bearing a solid tumor mass. Tumor growth was monitored until the desired size was about $0.3-0.6 \mathrm{~cm}^{3[12]}$.

\section{B-Experimental design}

\section{Animals}

Fifty Swiss male albino mice, 8 weeks of age, weighing 19-20gm were obtained from the animal breeding house of the National Research Centre (NRC), Dokki, Cairo, Egypt. The Animals were acclimatized for laboratory conditions at room temperature for two weeks. The animals were housed in meshed cages properly ventilated and with normal light and dark cycles. They were allowed free access to water and balanced diet (formula containing carbohydrates, proteins, fats and vitamins) was purchased from animals feeding supermarket.
Mice were equally divided into five groups, ten animals each. G1 negative control group, The rest of animals were inoculated intramuscularly with $0.2 \mathrm{ml}$ of EAC suspension. Twenty-four hours after tumor transplantation, the animals were divided into the other four group(GII, G III, G IV and $\mathrm{G} \mathrm{V}$ ). All animals were allowed free access of food and water.

\section{I-The experimental groups}

\section{G I; Negative Control group.}

\section{G II; Tumor inoculated group (Positive Control group)}

Animals bearing tumor mass were kept untreated and were considered as "positive control group".

\section{G III; Cisplatin treated group.}

Animals bearing tumor mass were treated with Cisplatin in a low dose ( $3 \mathrm{mg} / \mathrm{kg}$ body weight per week) intra peritoneally (i.p) every Monday, for three weeks starting from the 11th day of tumor cells inoculation until day 35 .

\section{GIV; Yeast treated group.}

Animals bearing tumor mass were injected intramuscularly (IM) with $1 \mathrm{ml}$ of yeast suspension 3 times /week starting from the 11th day of tumor cells inoculation until day 35 .

\section{$G$ V; Cisplatin and yeast treated group.}

Animals bearing tumor were injected with $1 \mathrm{ml}$ of yeast suspension 3times /week, as well as IP injection with Cisplatin in the same dose as GIII.

Every week till the end of the experiment, the body weight changes were calculated and then statistically analyzed. Also avernier caliber was used to measure tumor size data that was plugged into the following formula: $\mathrm{TV}\left(\mathrm{mm}^{3}\right)=0.52 \mathrm{AB}^{2}$, where $\mathrm{A}$ is the minor axis and $\mathrm{B}$ is the major axis. This was done at the beginning of the experiment and at the end. The changes were calculated and then statistically analyzed ${ }^{[13]}$.

On day 35, mice were scarified under light ether anesthesia then decapitation was accomplished. Blood was collected by direct cardiac puncture using heparinized syringes for complete blood picture analysis. The changes were recorded and then statistically analyzed. Gastrocenimius muscle with solid tumor tissue within the muscle were excised for histological studies.

\section{Light microscopic technique}

Musclespecimens were fixed immediately in Bouin's Fluid for 24 hours. Dehydration was then applied by immersing the specimens in in ascending grades of alcohol. The specimens were cleared by xylene then were infiltrated in molten paraplast wax. Paraplast blocks were then prepared. Serial $5 \mu \mathrm{m}$ thick sections were cut using a rotatory microtome, and every three consecutive sections 
were mounted on a clean glass slide. The slides were stained with hematoxylin and eosinfor routine histological examination $^{[14]}$ and Masson's trichromefor demonstration of collagen ${ }^{[15]}$. Some sections were put on adhesive slides for Bcl2 immune - histochemical staining for detection of apoptosis ${ }^{\mathrm{s}[16]}$.

\section{Morphometric study}

Numbers of BCL2 positive cells and morphometric analysis of area percentage of collagen fibers

Lieca light microscope(LiecaQwin 500 LTD image analysis microscope)at Faculty of Dentistry, Al-Azhar University, was used to estimate A: The numbers of BCL2 positive cells The results were expressed as cell number at $\mathrm{X}$ 400 magnification ${ }^{[17]}$. B- Morphometric analysis was done from ten different sections, ten non-overlapping fields and from ten different animals in each group to measure area percentage of the collagen fibers stained with Masson's trichrome stains in 10 randomly selected microscopic fields at x 200 magnification.

\section{Statistical study}

Statistical studies to evaluate body weight, tumor size changes, cytophotometric measurements of collagen fibers stained by Masson trichrom and also the BCL2 positive cells, were carried out and statistically evaluated. In addition the changes in the number of red blood cells and white blood cells were measured.

Data evaluation was expressed as means \pm standard deviation (SD) and analysis was performed using SPSS program. T test was used for comparison between the experimental groups. $P$ value $\leq 0.05$ was considered statistically significant ${ }^{[18]}$.

\section{RESULTS}

\section{A- Haematoxylin and eosin results \\ GI Control group (Negative control group)}

Examination of H\&E stained longitudinal sections (LS) in the gastrocnemius skeletal muscle of the GI showed that muscle fibers were parallel, long, non branching, cylindrical and multinucleated. The muscle fibers had acidophilic sarcoplasm with clear transverse striation of alternating dark and light bands. Multiple, flat and peripherally located nuclei were seen just beneath the sarcolemma. The muscle fibers were separated by connective tissue (C.T) endomysium (Figure 1A). The muscle fibers of $H \& E$ stained transverse sections (TS) of G I gastrocnemius muscle appeared polyhedral in shape with acidophilic sarcoplasm having peripheral nuclei. The fibers were grouped in bundle (fassiculi), invested with dense connective tissue perimysium, contained blood capillaries as well as nerve fibers and other connective tissue elements (Figure 1B).

\section{G II Tumor inoculated group (positive control group)}

H\&E stained gastrocnemius muscle from G II showed The muscle fibers were infiltrated by sheets of pleomorphic, small and chromatophilic tumor cells with highly atypical vesicular nuclei having irregular nuclear membranes of variable shapes (ovoid, spindle or rounded) and abundant cytoplasm with some coherence to each others. Also, there were considerable number of abnormal mitotic figures (Figures 2A and 2B). Muscle fibers appeared more thinner and widely separated from each other, most of the muscle fibers appeared degenerated, possessed wavy appearance and infiltrated by mononuclear cellular infiltration with bland nuclei( Figure 2C). Fibrous C.T septa separated bundles of muscle fibers and tumor tissue. Deformed, small and angular fragmented muscle fibers were observed. Blood vessels and fat cells were also present (Figure 2D).

\section{Group III Cisplatin treated group}

Comparing this group to previous group II, examination of H\&E stained LS in the gastrocnemius muscle of G III showed, muscle fibers intermingled with tumor cells. These muscle fibers developed signs of necrosis; and appeared homogenous, interrupted and widely separated from each other(as a result of edema).These muscle fibers experienced loss of their transverse striations and loss of their peripheral located nuclei. The tumor cells infiltrating the muscular tissue were less numerous. Considerable inflammatory reaction represented by abundant mononuclear cellular infiltration was also noticed in the tumor areas. There were obviously deep basophilic areas of necrotic debris and mononuclear cellular aggregations, especially seen at the border line (Figure 3A).Animals of G III treated with Cisplatin showed, T.S muscle fibers intermingled with tumor cells developed signs of degeneration; were fragmented and widely separated from each others. Some muscle fibers appeared rounded while others were small and angular(Fig.3B).Necrotic tumor area showed much cellular debris (Figures 3B, 3C).

\section{G IV Yeast treated group}

Comparing this group to the untreated G II, H\&E stained LS and TS in the gastrocnemius muscle from G IV showed that the muscle fibers surrounding the tumor area looked like the negative control sections. However, the tumor area exhibited degenerative muscle fibers with atrophic changes giving the shape of small angular muscle fibers with some vacuoles and necrotic tumor cells showing cellular debris and pyknotic nuclei. In addition, there were considerable inflammatory reactions represented by abundant number of mononuclear cellular infiltration. The tumor cells infiltrating the muscular tissue were relatively less than those of the untreated GII. Excess fibrous tissue could be also be detected (Figures 4A,4B and 4C). 


\section{G V Cisplatin and Yeast treated group}

$\mathrm{G} V$ showed that the muscle fibers were nearly comparable to those of control group partially regained their normal appearance. Minority of the fibers possessed wavy appearance. Marked diminution of tumor cells infiltrating the muscular tissue was observed in comparison to the untreated GII. Considerable inflammatory reaction (compare with other groups) represented by numerous mononuclear cellular infiltration was also noticed infiltrating the tumor areas (Figure 5A).

H\&E stained TS of the same group showed minimal degenerative changes of muscle fibers (Figure 5B). Minimal islands of tumor cells infiltrated by mononuclear cellular infiltration, multiple large islands of aggregated leukocytic cells together with areas of necrosis. (Figure 5C). Condensed, pyknotic nuclei with indentation and disintegration of nuclear chromatin. Necrotic tumor area appeared homogenous and acidophilic with much basophilic debris. Fat cells were also noticed (Figure 5D).

\section{B-Masson's trichrome results}

Masson's trichrome stained sections of gastrocnemius muscle from the G I revealed minimal amount of collagen fibers within the connective tissue in between the muscle fibers and around blood vessels (Figure 6A), which mildly increased in GII (Figure 6B), moderately increased in GIII (Figure 6C), markedly increased in GIV (Figure 6D) and massively increased in GV (Figure 6E).

\section{C-Immuno-histochemical results}

Immunohistochimical reaction to detect BCL2 stained with Avidine-biotin peroxidase and Hematoxylin sections of G I showed strong cytoplasmic reactions for BCL2 marker were detected and were seen as brown granules within the cytoplasm of the positive cells (muscle fibers and tumor cells) (Figure 7A). While sections of GII showed a moderately positive reaction to BCL2 marker if compared to G I. (Figure 7B). However sections of EC-bearing mouse of treated groups (GIII,G IV and GV), showed weak positive cytoplasmic reactions for BCL2 marker. i.e. few cells contain brownish granules if compared to GII (Figures 7C,7D and 7E).

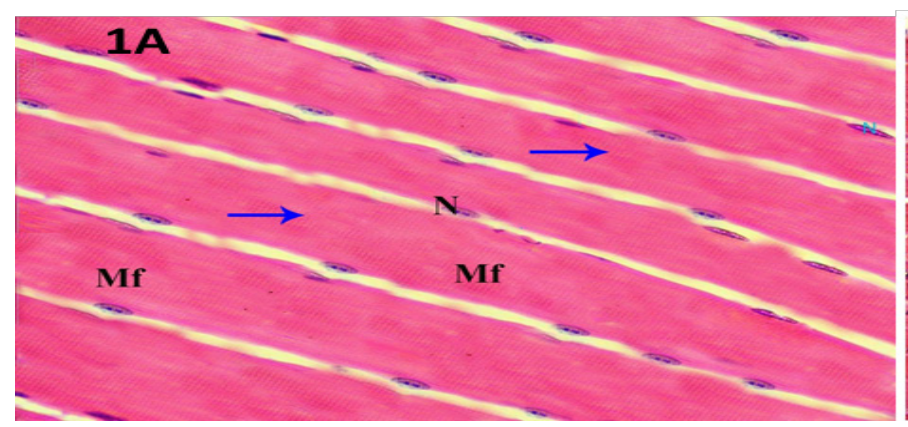

\section{D-Morphometric and statistical results}

The experimental animals were weighed at the end of the experiment, it was noticed that the least mean of animal body weight was in the G II $(12.14 \pm 1.49)$ followed by G III $(22.29 \pm 1.23)$, G IV $(22.43 \pm 0.81)$ then GV $(23.00 \pm 0.60)$ respectively. However, the highest mean body weight was recorded in G I $(29.00 \pm 0.82)$ these findings were of statistically significant values $(P<0.05)$

The size of tumor among the experimental groups revealed that the least mean was in $\mathrm{GV}(0.24 \pm 0.03)$ followed by G IV $(0.45 \pm 0.08)$ and G III $(0.47 \pm 0.09)$ respectively. However, the highest mean was in G II $(1.24 \pm 0.18)$. These findings were of statistically significant values $(P<0.05)$ (Table 1 and Histogram 1$)$.

Measurement of collagen area percentage among the experimental groups showed that the least mean was in G I (1.52 \pm 0.06$)$ followed by G II $(2.51 \pm 0.11)$, GIII $(6.8 \pm 0.37)$ then GIV $(11.2 \pm 0.38)$ However, the highest mean was in $\mathrm{GV}(22.09 \pm 0.30)$. These findings were of statistically significant values $(P<0.05)$.

Statistical study of the means numbers of BCL2 positive cells showed that the highest mean was recorded in GI $(21.33 \pm 2.42)$ followed by GII $(16.71 \pm 1.11)$, GIII $(9.86 \pm 1.21)$ then GIV $(8.57 \pm 0.79)$ respectively. However, the lowest mean was recorded in $\mathrm{GV}(5.00 \pm 1.15)$. These findings were of statistically significant $(P<0.05)$. (Table 1 and Histogram 2).

Comparison between studied groups as regards RBCs count $/ \mathrm{ul} \times 106$ showed that the highest mean was recorded in $\mathrm{G} \mathrm{I}(8.18 \pm 0.198)$ followed by G IV $\left(7.29 \pm 0.144^{* b}\right)$, G II $\left(6.35 \pm 0.203^{* a}\right)$ then G V $\left(5.52 \pm 0.08^{* b}\right)$ However, the lowest mean was recorded in G III $\left(4.79 \pm 0.06^{* b}\right)$. These findings were of statistically significant $(P<0.05)$. (Table1 and Histogram 3).

Comparison between studied groups as regards WBCs count / $\mu 1 \times 10^{3}$ showed that the highest mean was recorded in G V $\left(23.9 \pm 5.05^{* b}\right)$ followed by G IV $\left(16.8 \pm 5.39^{* b}\right)$, GII $\left(16.5 \pm 3.70^{*}\right.$ a $)$ then G III $\left(10.3 \pm 1.09^{* b}\right)$ However, the lowest mean was recorded in GI $(7 \pm 0.4)$. These findings were of statistically significant $(P<0.05)$. (Table 1 and Histogram 4).

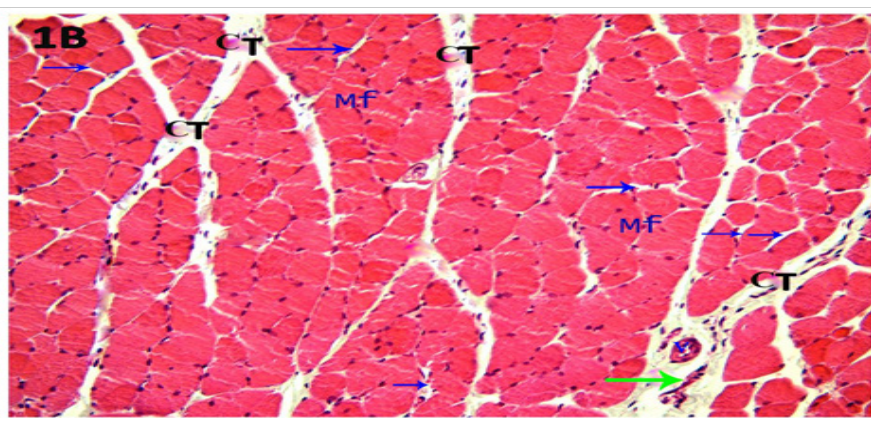

Fig. 1: Photomicrograph in the gastrocnemius muscle of the control group A-LS showing:Parallel muscle fibers (Mf) with peripheral, multiple and elongated nuclei. B-TSshowing: Fasciculi of fibers (Mf) with peripherally located nuclei are separated by perimysium (CT) containing blood vessels (V) and nerve fibers (green arrow). Endomysium can be noticed (blue arrow) (H\&E x 400\&200). 

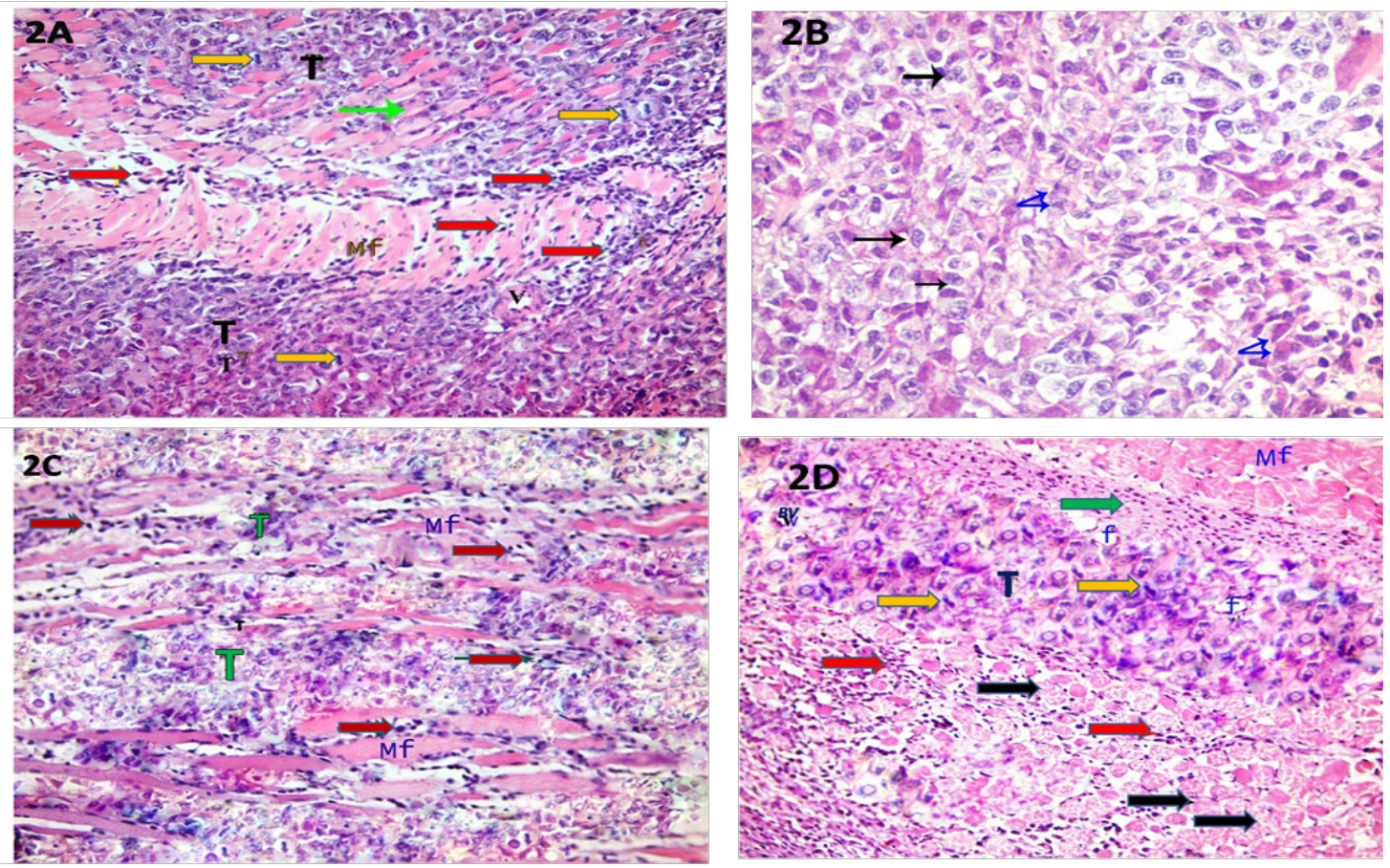

Fig. 2: Photomicrographs of sections in gastrocnemius muscle from GII showing A-Highly atypical wide sheets of neoplastic pleomorphic cells with highly atypical vesicular nuclei $(\mathrm{T})$ infiltrating between the destroyed degenerative muscle fibers (green arrow). Mononuclear cellular infiltration is noticed (red arrow). Some muscle fibers (Mf) at the edge of the neoplastic growth look normal. Multiple abnormal mitotic figures can also be detected (yellow arrow). B- neoplastic growth of highly atypical irregular vesicular nuclei (black arrow) with abundant cytoplasm.. Cells show some coherence to each other(blue arrows). C- LS: Thin irregular parallel muscle fibers possess wavy appearance and are widely separated from each other (Mf) that are markedly infiltrated by plenty of pleomorphnuclear tumor cells(T) and are associated with mononuclear cellular infiltration (red arrow). D-TS; fibrous C.T septa (green arrow) between bundles of muscle fibers (Mf) and tumor tissue (T). Deformed, small and angular fragmented muscle fibers, widely separated from each other (black arrow) are infiltrated by sheets of pleomorphic tumor cells $(\mathrm{T})$ with multiple irregular mitotic fingers (yellow arrow)and some scattered inflammatory cells(red arrow). Blood vessels (BV) and fat cell (F) can also be seen. (H\&E x 200, 400, $200 \& 200$ ).
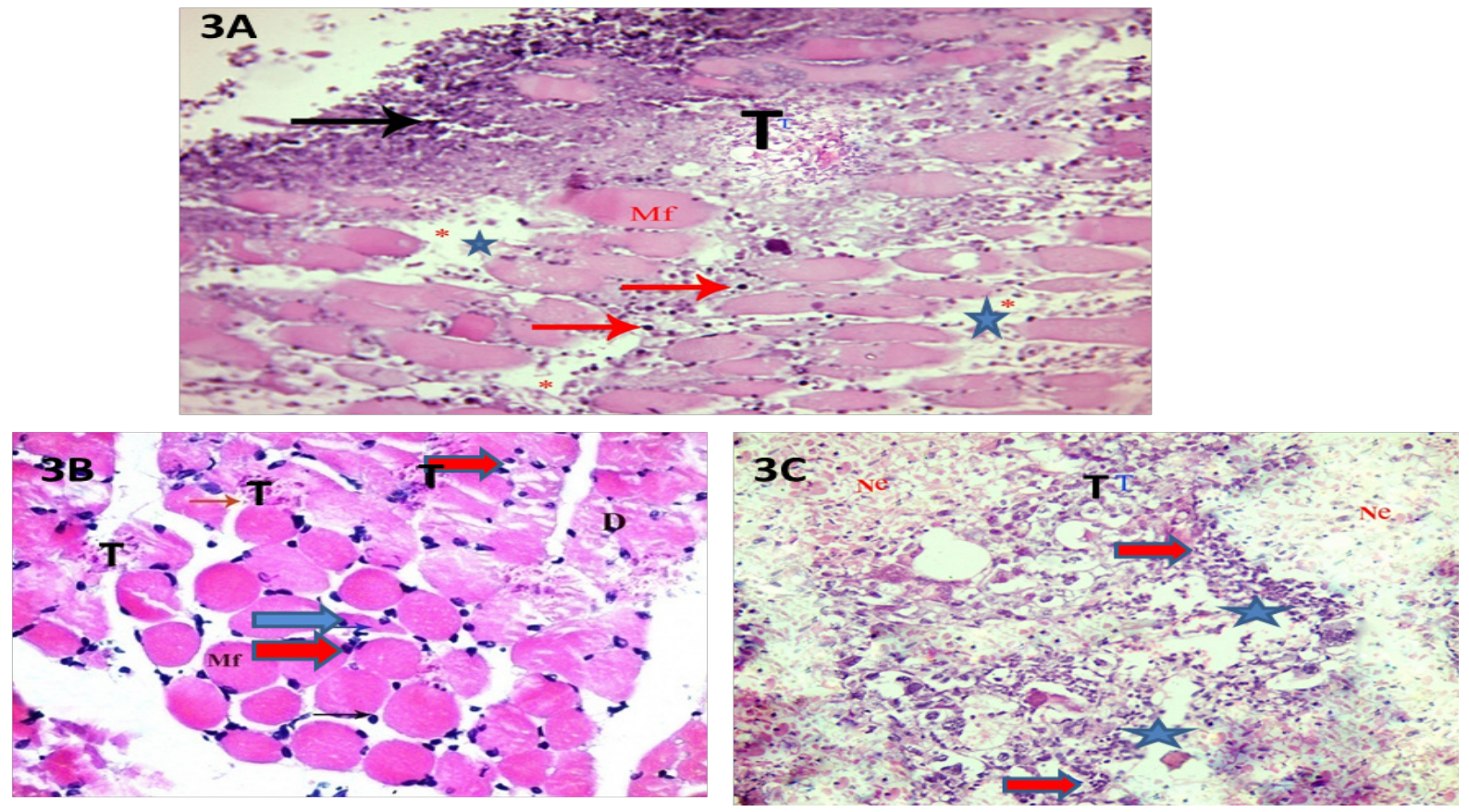

Fig. 3: Photomicrographs of gastrocnemius muscle from G IIIA-LS showing: Less numerous tumor cells (T)than G II. The fibers are homogenous and interrupted and widely separated from each other by edema $(*)$ with loss of their transverse striations and peripheral nuclei(MF)..Scattered mononuclear cellular infiltration(red arrows)is seen. Aggregations of mononuclear cellular infiltrations are noticed at the border line (black arrows).B- TS: Less numerous tumor cells (T) irregularly fragmented muscle fibers(D). Rounded muscle fibers (Mf), small and angular fibers (blue arrow), scattered leucocytic infiltrations (red arrows) C-TS ; Less numerous tumor cells (T)are associated with leucocytic infiltrate (red arrows). Necrotic tumor shows much cellular debris (Ne). Edema is also noticed $\left(^{*}\right)(\mathrm{H} \& \mathrm{E}, \mathrm{x} 200,400 \& 200)$. 

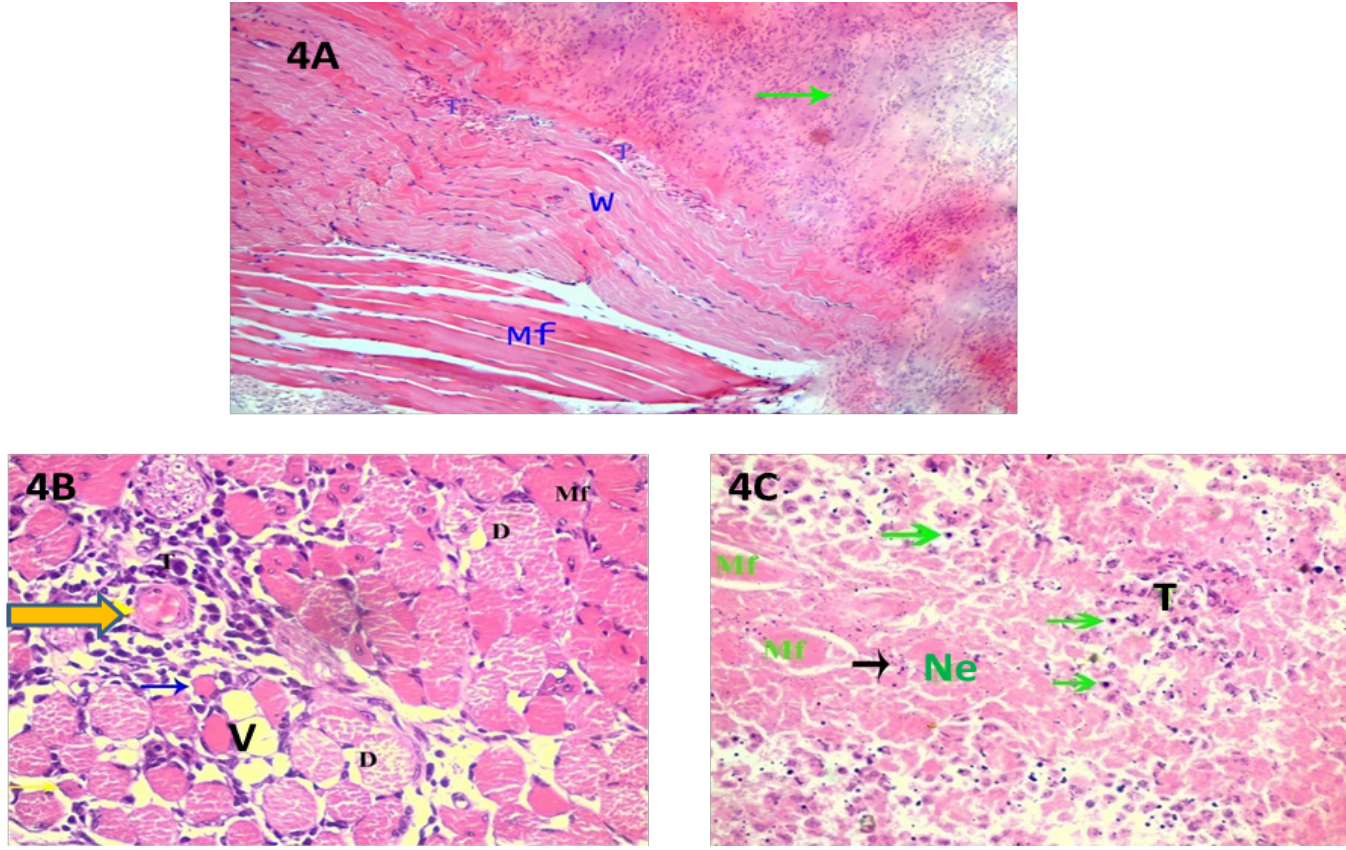

Fig. 4: Photomicrographs in the gastrocnemius muscle of GIV showing :A-LS, the muscle fibers which are not infiltrated with tumor cells appear normal (Mf). However muscle fibers intermingled with tumor cell appear wavy (W). Tumor cells(T) infiltrating the muscular tissue are not as numerous as in the untreated G II. Excess fibrous tissue is noticed(green arrow). B- TS : Some muscle fibers appear normal (Mf), others are irregular, fragmented (D), showing atrophic changes or small angular muscle fibers (blue arrow). Tumor cells are less numerous (T) than GII, inflammatory cells aggregates around muscle spindle (yellow arrow) and others infiltrated the muscular tissue. Some vacuoles (V)can also be seen. C-Pyknotic nuclei (green arrow), necrotic tumor area(Ne) with plenty of cellular debris (black arrow) and degenerative muscle fibers(Mf) (H\&E, x 100, 400\& 400).
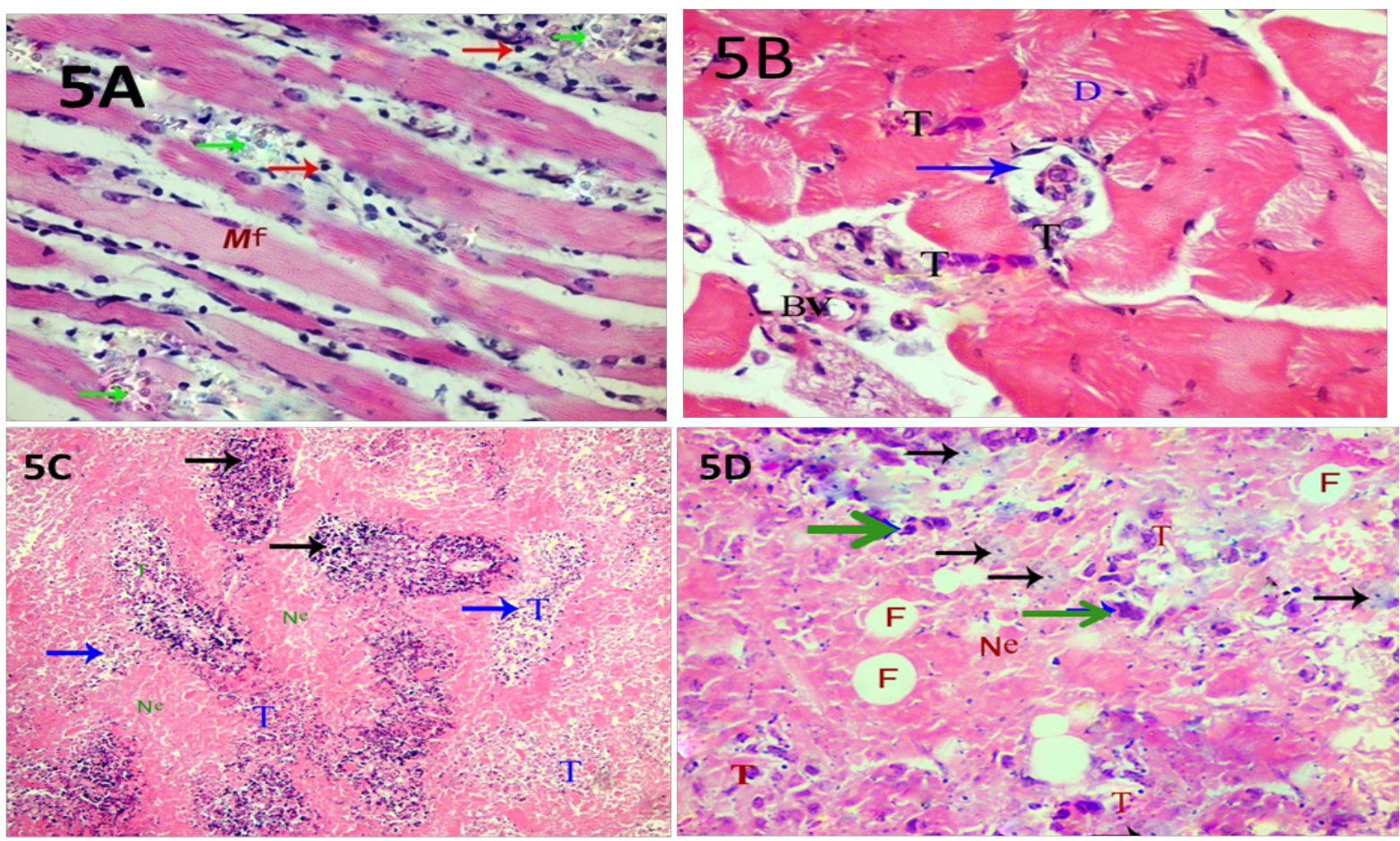

Fig. 5: Photomicrographs in the gastrocnemius muscle from EC-bearing mouse G VA- LS showing; Parallel muscle fibers (Mf) with multiple flat peripheral located nuclei more or less similar to control group, but they are widely separated from each other. Tumor cells (green arrow) infiltrate the muscular tissue and are less numerous than GII. Mononuclear cellular infiltrations can also be noticed (red arrow). B- TS showing: minimal degenerative changes of muscle fibers (D). Marked decrease in the presence of number tumor cells (T) infiltrating the muscular tissue compared to the untreated G II. Also muscle spindle (blue arrows) and blood vessels (BV) are seen. C- Few tumor cells (T) infiltrated by inflammatory cells (blue arrow). Multiple large islands of aggregated leukocytic cells (black arrow), together with areas of necrosis (Ne). D-TS showing; minimal tumor cells (T), condensed / pyknotic nuclei (black arrows), indentated and disintegrated nuclear chromatin (green arrow), necrotic areas (Ne) and fat cells (F)(H\&E, x 400, 400,100\&400). 

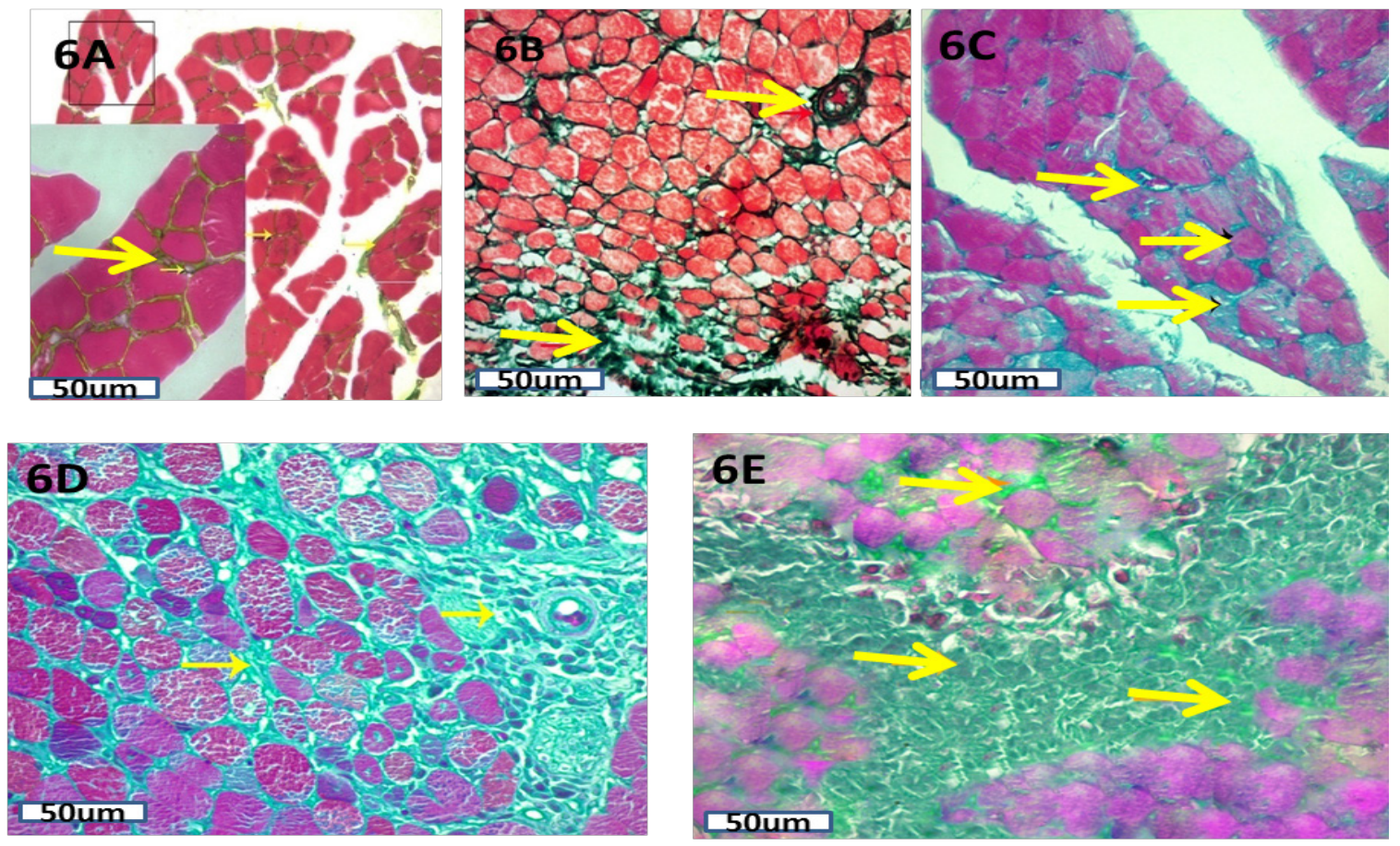

Fig. 6: Photomicrographs in gastrocnemius muscle of experimental groups showing;. A- TS. From G Ishowing, delicate collagen fibers (arrow). within connective tissue in between the muscle fibers. The inset is higher magnification to show minimal collagen fibers in C.T endomysium in between the muscle fibers. B-T.S of GII showing: Mild increase in collagen fibers (yellow arrow)C-TS from G III showing: Moderately increase in collagen fibers in between muscle fibers (Mf)(yellow arrow). D-TS from G IV showing: Marked increased collagen fibers (yellow arrow) within connective tissue in between the muscle fibers. .E- TS from G V showing; Massive presence of collagen fibers( yellow arrow) within connective tissue in between muscle fibers, collagen fibers may sweep over the muscle fibers. (Masson's trichrome $\mathrm{x}$ 40).
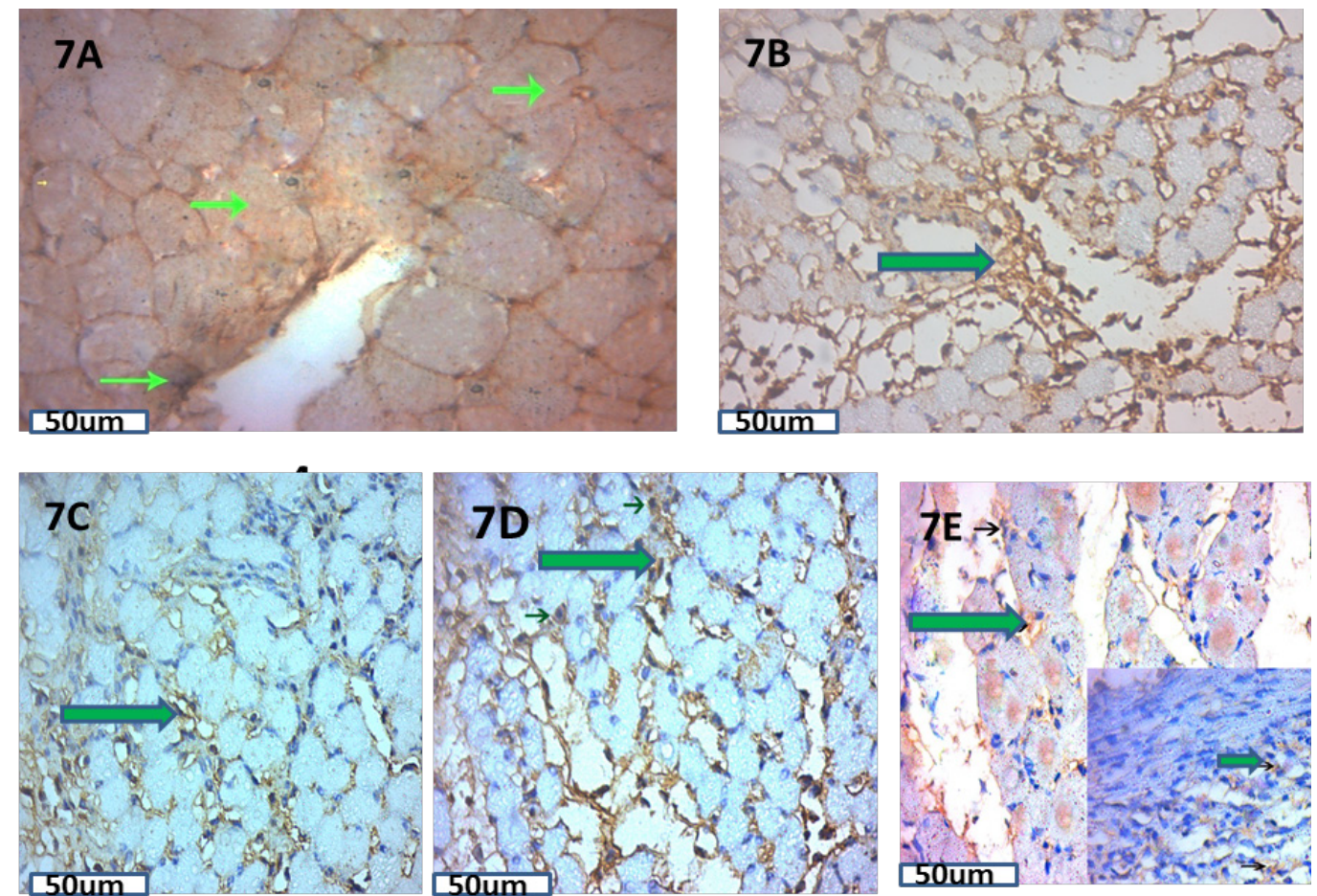

Fig. 7: Photomicrographs in gastrocnemius muscle A- TS of G I showing; strong positive cytoplasmic reactions for BCL2 (green arrow). BT.S in G II showing; Moderate positive cytoplasmic reactions for BCL2(green arrow).. C-T.S of G III showing: Weak positive cytoplasmic reactions for BCL2 of muscle fibers(green arrow).D- TS in G IV showing: Weak positive cytoplasmic reactions for BCL2 of muscle fibersand tumor cells(green arrow). E- T.S of G V showing: Weak positive cytoplasmic reactions for BCL2 of muscle fibers and tumor cells(green arrow). (Avidin -biotin peroxidase \& $\mathrm{H}, \mathrm{X} 40$ ). 
Table 1: Comparison between studied groups as regards weight of animals, Size of tumor, Collagen area percentage,BCL2 positive cells, $\mathrm{RBCs}$ and WBCs count $/ \mu$ lin different experimental groups.

\begin{tabular}{|c|c|c|c|c|c|c|}
\hline $\begin{array}{l}\text { Studied } \\
\text { groups }\end{array}$ & $\begin{array}{l}\text { Weight of animals. } \\
\text { Mean } \pm \text { SD }\end{array}$ & $\begin{array}{l}\text { Size of tumor } \\
\text { Mean } \pm \text { SD }\end{array}$ & $\begin{array}{c}\text { Collagen area } \\
\text { percentage }\end{array}$ & $\begin{array}{l}\text { BCL2 positive cells } \\
\text { Mean } \pm \text { SD }\end{array}$ & $\begin{array}{c}\text { RBCscount } / \mu 1 \times 106 \\
\text { Mean } \pm \text { SD }\end{array}$ & $\begin{array}{c}\text { WBCs count } / \mu 1 \times 103 \\
\text { Mean } \pm \text { SD }\end{array}$ \\
\hline G I & $29.00 \pm 0.82$ & $0.00 \pm 0.00$ & $1.52 \pm 0.06$ & $21.33 \pm 2.42$ & $8.18 \pm 0.198$ & $7 \pm 0.4$ \\
\hline G II & $12.14 \pm 1.49^{\mathrm{ka}_{\mathrm{a}}}$ & $1.24 \pm 0.18^{*_{a}}$ & $2.51 \pm 0.11^{*_{a}}$ & $16.71 \pm 1.11^{* a}$ & $6.35 \pm 0.203^{* a}$ & $16.5 \pm 3.70^{*_{a}}$ \\
\hline G III & $22.29 \pm 1.23^{* b}$ & $0.47 \pm 0.09^{* b}$ & $6.8 \pm 0.37^{* \mathrm{~b}}$ & $9.86 \pm 1.21^{* \mathrm{~b}}$ & $4.79 \pm 0.06^{* b}$ & $10.3 \pm 1.09^{* b}$ \\
\hline G IV & $22.43 \pm 0.81^{* b}$ & $0.45 \pm 0.08^{* \text { b }}$ & $11.2 \pm 0.38^{* b}$ & $8.57 \pm 0.79^{* b}$ & $7.29 \pm 0.144^{* b}$ & $16.8 \pm 5.39^{* b}$ \\
\hline G V & $23.00 \pm 0.60^{* b}$ & $0.24 \pm 0.03^{* b}$ & $22.09 \pm 0.30^{* b}$ & $5.00 \pm 1.15^{* \mathrm{~b}}$ & $5.52 \pm 0.08^{* \mathrm{~b}}$ & $23.9 \pm 5.05^{* b}$ \\
\hline
\end{tabular}

T- Test is a test for comparison between two groups, ${ }^{*} P \leq 0.05$ statistically significant.

"compared with control group (GI)

compared with (GII)

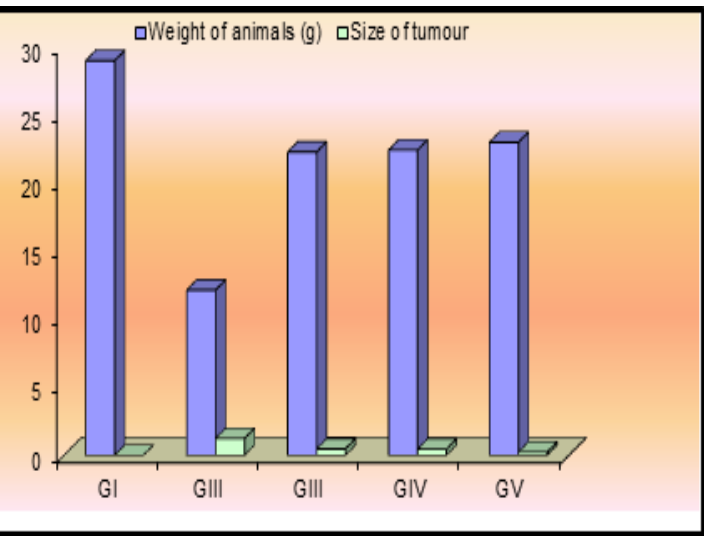

Histogram I: Body weight and size of the tumor, in different experimental groups.

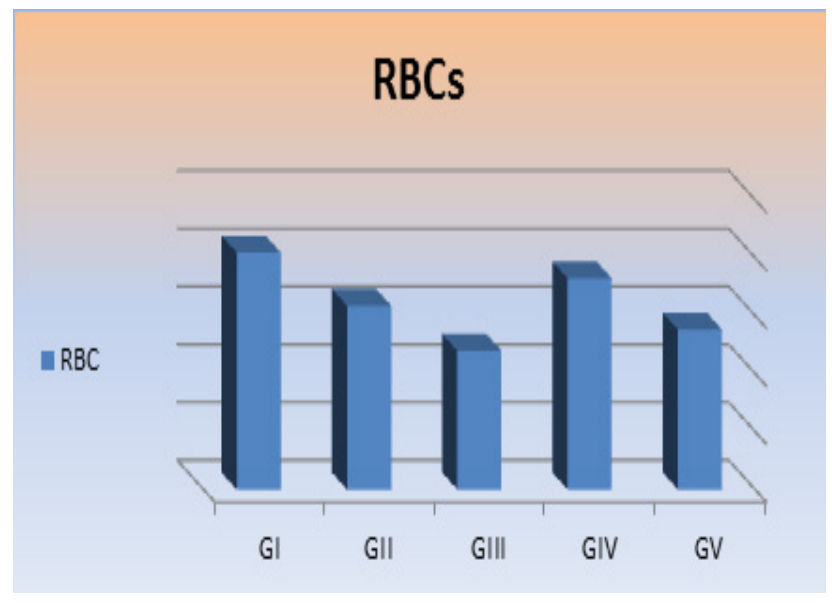

Histogram 3: The number of $\mathrm{RBCs} / \mu 1$ in the different experimental groups

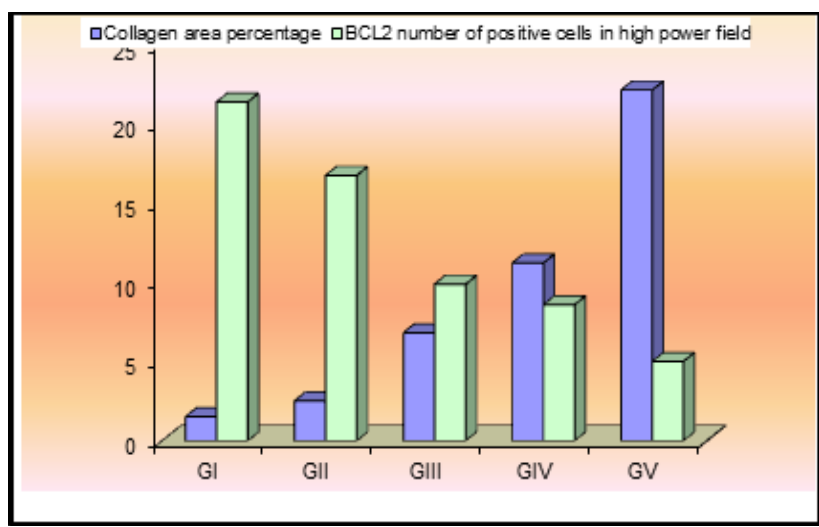

Histogram 2: Mean collagen area percentage and mean numbers of BCL2 positive cells, in different experimental groups.

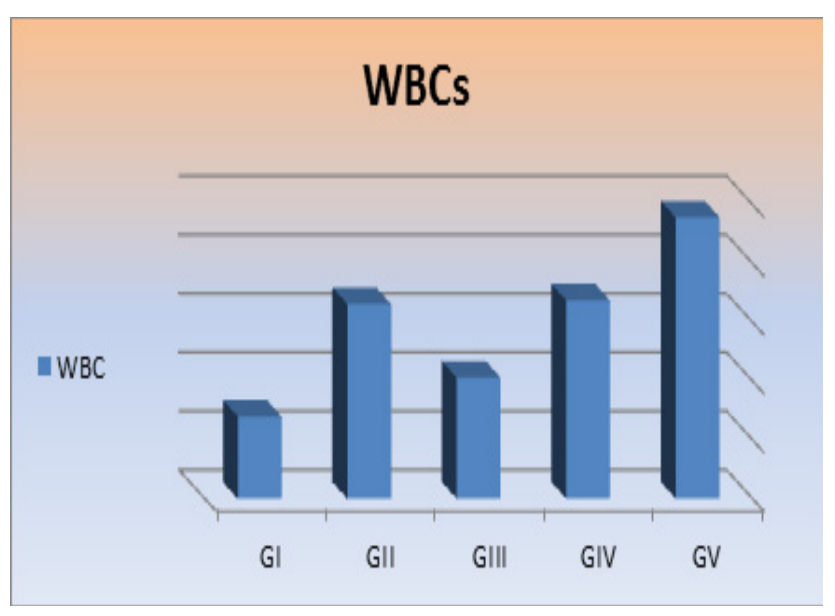

Histogram 4: The number of WBCs/ $\mu \mathrm{l}$ in the different experimental groups 


\section{DISCUSSION}

Herbal treatment is the best replacement for treating cancer avoiding a variety of physical side effects caused by the chemotherapy and radiation therapy. This treatment option can effectively avoid the damaging of normal healthy cells near cancer cells ${ }^{[13]}$.

Ehrlich ascites carcinoma (EAC) was chosen in the current study as a rapidly growing experimental tumor model where different experimental designs for anticancer agents can be applied ${ }^{[19]}$.

Cisplatin was used in a low dose $3 \mathrm{mg} / \mathrm{kg}$ body weight in the present study. It was given as an intra-peritoneal (IP) injection once aweek for three weeks to avoid its side effect $^{[10]}$.

The histological changes which occurred as result of inoculation of EAC cells in gastrocenimius muscle in G II were in the form of compact aggregated tumor cells within the muscular tissues. Tumors cells showed pleomorphism; sheets of small chromatophilic tumor cells with highly atypical vesicular nuclei with irregular nuclear membranes. Nuclei exhibited variable shapes (ovoid, spindles or rounded) with abundant cytoplasm and some coherence to each others. Also, there was considerable number of abnormal mitotic figures. These findings are in agreement with Ghoneum et al., (2008) ${ }^{[13]}$ who found poorly differentiated carcinoma infiltrating into the skeletal muscles and adipose tissue after tumor inoculation.

GII muscle fibers intermingled with tumor cells and became more thinner, angular fragmented and widely separated from each other if compared to G I. They developed signs of degeneration and possessed wavy appearance. Fibrous C.T septa were present between bundles of muscle fibers and tumor tissue.

These findings are in agreement with Teixeira et al., (2006) ${ }^{[19]}$ who found interaction between skeletal abdominal muscle and Ehrlich ascites tumor cells, in which ascites induced inflammation and angiogenesis in this tissue of mice bearing-tumor.

The observation of Frajacomo et al.,(2016) ${ }^{[20]}$ that the histological appearance of the transverse sections of skeletal muscle inoculated with tumor cells despite many fibers appeared with a central nuclei, which is suggestive of progressing regenerative process, there were many angular fibers, indicative of apoptotic development. Also noticed decreased muscle fibers diameter and changed in there morphological appearance these, are in accordance with our findings.

The current results in which the muscle fibers intermingled with tumor cells became more thinner, widely separated from each other, associated with mononuclear cellular infiltrations and compact aggregated pleomorphic tumor cells within the muscular tissues and the observed number of abnormal mitotic figures of GII are in accordance with those of Abdel-Gawada et al., (2016) ${ }^{[21]}$ who stated that in the tumor bearing group, muscle fibers were widely separated with a few and dispersed interstitial infiltrative cells was noticed, malignant cells showed anaplastic nature, with frequent mitotic figures and a huge heteroplasmy with cellular and nuclear pleomorphism.

Cellular infiltration associated with tumor cells proliferation in GII was in agreement with Fecchio et al.,(1990) ${ }^{[22]}$ who found after inoculation of EAC cells, the number of peritoneal leukocytes remained unchanged till the sixth day. Subsequently, the number of cells increased as a consequence of tumor growth.

Chen et al., (2018) ${ }^{[23]}$ estimated that around $25 \%$ of the malignancies are induced by chronic inflammation, where altered levels of pro-inflammatory and proangiogenic factors are recorded in different cancers.

This has been explained by Salem et al., $(2014)^{[24]}$. who mentioned that activation of key inducers of proinflammatory cascades, including the transcription factors and nuclear factor kappa beta (NF- $\kappa \beta)$, leads to augmentation of cell proliferation, apoptotic evasion and metastasis

The mechanism of action of these processes was stated by different researchers ${ }^{[25,26 \& 27]}$ who stated that TNF- $\alpha$ is a key player in cancer-related inflammation and promotes lymphangiogenesis and lymphatic metastasis in clinically relevant human and mouse epithelial carcinoma tumor models through numerous mechanisms, including tumor inflammation, tumor angiogenesis, and inducing epithelial-mesenchymal transition. Also TNF- $\alpha$ is a major inflammatory mediator that induces many changes in endothelial cell gene expression, together with induction of adhesion molecules and integrins, therefore acting as an autocrine growth factor for tumor angiogenesis.

Upon histological examination of mice of GIII(Cisplatin treated group), muscle fibers developed signs of necrosis; and appeared homogenous, fragmented interrupted and widely separated from each other most probably due to occurrence of edma, with loss of their transverse striations and loss of their peripheral located nuclei. Some muscle fibers appeared rounded while the others were small and angular. The tumor cells infiltrating the muscular tissue were less numerous compared to the untreated GII. Also there was inflammatory reaction.

Nieto (2003) ${ }^{[28]}$ remarked that when Cisplatin enters the cells, the chloride ligands are replaced by water molecules and, in another study ${ }^{[29]}$ the author showed a significant increase in percentages of early apoptosis in the EAC cells treated with Cisplatin and sulfur containing agent dimethyl sulfoxide, compared with cells treated with Cisplatin alone and also found marked inhibition of tumor growth. Histopatholgical evaluation in this study showed that Cisplatin treatment causes a noticeable necrosis in proximal tubules and disintegration of the tubular epithelial cells. 
The muscle fibers in GIV(Yeast treated group) surrounding the tumor area looked like the negative control sections. However, the tumor area exhibited degenerative muscle fibers mixed with tumor cells. The tumor cells infiltrating the muscular tissue were relatively less than those of the untreated GII. Fibrous tissue showed marked increase and necrotic tumor cells appeared with cellular debris. There were inflammatory reactions.

Our finding are in agreement with Ghoneum et al., $(2008)^{[13]}$ who reported that, yeast-treated tumor tissue showed ischemic necrosis after 35 days post-treatment with yeast. Ischemic necrosis of the center of the tumor showing minimal viable islands of tumor cells, and necrotic center with excessive leukocytes and cell debris.

Yeast $\beta$-glucanis is one of the immunomodulating substances extracted from Saccharomyces cerevisiae (baker yeast). Fungal cells mass consists mainly of $\beta$-glucans, which is a major structural component of various yeast cells and is vital for cell functions and has potent NK enhancement ${ }^{[30]}$. NKcells are a major components of innate immunity that plays an important role in immune action against cancer ${ }^{[31]}$

Another interesting finding of this study is that yeast administration resulted in increase leukocytes infiltrating the tumor area. This result was also documented by Ghoneum et al., (2008) ${ }^{[13]}$ who found that the histopathology of the yeast-treated tumor showed many leukocytes situated at the tumor area this, rarely observed in the control mice.

$\mathrm{G} \mathrm{V}$ showed that the muscle fibers were nearly comparable to those of control group partially regained their normal appearance. Minority of the fibers possessed wavy appearance. Marked diminution of tumor cells infiltrating the muscular tissue was observed in comparison to the untreated GII. Minimal islands of tumor cells infiltrated by mononuclear cellular infiltration, multiple large islands of aggregated leukocytic cells together with areas of necrosis. (Figure 5C). Condensed, pyknotic nuclei with indentation and disintegration of nuclear chromatin. Necrotic tumor area appeared homogenous and acidophilic with much basophilic debris. Fat cells were also noticed.

Masson's trichrome stained sections of gastrocnemius muscle and measurement of collagen area percentage among the experimental groups revealed that the least mean was in G I $(1.52 \pm 0.06)$ followed by G II $(2.51 \pm 0.11), \mathrm{G}$ III $(6.8 \pm 0.37)$ then G IV $(11.2 \pm 0.38)$ respectively. However, the highest mean was in $\mathrm{G} \mathrm{V}$ $(22.09 \pm 0.30)$. These findings were statistically significant.

The increased in collagen area percentage in GII are in concord with Ghoneum et al., (2008) ${ }^{[13]}$ who showed that the untreated tumor cells showed simply $9 \%$ focal apoptosis/fibrosis.

The increased in collagen area percentage in GIII are in concord with Spliethoff et al., (2014) ${ }^{[32]}$ stated that the pathologic response to Cisplatin in tumor model corresponds with the replacement of viable tumor tissue by fibrosis, without a considerable increase in necrosis.
The increased in collagen area percentage in GIV are in concord with Ghoneum et al., (2008) ${ }^{[13]}$ who found on examination of yeast treated tumors extensive tumor apoptosis within the lesion with extensive fibrosis, and small foci of the residual tumor tissues, in which $80 \%$ of the tumor cells had undergone apoptosis/fibrosis resulting in a complete loss of tumor configurations.

The statistical study of immune -histochemical response for detecting BCL2 positive cells, showed that the highest mean was recorded in G I $(21.33 \pm 2.42)$ followed by G II $(16.71 \pm 1.11), \mathrm{G}$ III $(9.86 \pm 1.21)$ then $\mathrm{G} \mathrm{IV}(8.57 \pm 0.79)$ and the lowest mean was recorded in $\mathrm{G} \mathrm{V}(5.00 \pm 1.15)$. These findings were of statistical significance $(P<0.05)$. These results were in contrast with Pal, et al., (2001) $)^{[33]}$ who found that the reaction of $\mathrm{Bcl}-2$ remains unchanged in EAC.

Studies have shown that apoptosis is regulated by the balance between BCL2(B-cell lymphoma 2); antiapoptotic protein and Bax (BCL2-Associated X Protein); pro-apoptotic protein ${ }^{[34,35]}$. BCL2 oncoprotein regulates programmed cell death by providing survival advantage to rapidly proliferating cells ${ }^{[36]}$. BCL2 marker inhibit the cytochrome release because it prevents insertion of Bax into mitochondrial membrane $e^{[35]}$.

The percentage of apoptotic cells increased with increasing concentrations of Cisplatin and exposure time of cell culture to the drug. Gradually, time dependent down regulation of BCL2 gene was observed during Cisplatin treatment ${ }^{[37]}$.

In accordance with these findings, Elwakkad, et al., $(2018)^{[38]}$ reported that:Baker's yeast induces apoptotic effects and histopathological changes on skin tumors in mice.

Also $^{[13]}$ mentioned that Yeast-induced apoptosis in breast cancer was associated with an increase in Bax and a substantial decrease in expression of Bcl-2 resulting in alteration in the Bax: Bcl-2 ratio.

Several studies showed that Bcl-2 and Bax can adjust $\mathrm{Ca} 2+$ mobilization from the ER to the cytosol and mitochondria during apoptosis ${ }^{[39]}$.

The present study, demonstrated the changes of body weights of animals among the experimental groups. It revealed that the least mean was in the G II $(12.14 \pm 1.49), \mathrm{G}$ III $(22.29 \pm 1.23), \mathrm{G}$ IV $(22.43 \pm 0.81)$ and then $\mathrm{GV}(23.00 \pm 0.60)$. However, the highest mean was recorded in G I $(29.00 \pm 0.82)$ thesefindings were of statistically significant values $(P<0.05)$ group.

This drop in body weight of G II is explained by cancer cachexia. The loss of weight, mainly in skeletal muscle and adipose tissue, is not caused only by anorexia but also by systemic effects of the cancer which includes anemia and immunosuppression together with a number of biochemical changes ${ }^{[40]}$. Also there are different systemic biochemical effects of transplanted tumors in mice, including a decrease 
of liver catalase and plasma iron which taken together can be considered a cancer cachexia syndrome ${ }^{[20]}$.

Several studies suggest that cancer cachexia occurs as result of imbalance between degradation and protein synthesis, mediated among others by cytokines and reactive oxygen species ${ }^{[41,42]}$.

Skeletal muscle wasting might be mediated by excessive interleukins production, either by host or tumor cells, such as IL-6, IL-1, and TNF- $\alpha$ that are considered to be key drivers of the systemic inflammation cascade ${ }^{[41]}$.

Different therapeutic strategies have been tested to prevent or treat cancer-induced muscle wasting but none of them seem appropriate ${ }^{[43]}$.

Garcia et al.,(2013 ${ }^{[44]}$ stated that Cisplatin-induced weight and fat loss.Cisplatin increased markers of lipolysis in white adipose tissue (WAT) and of $\beta$-oxidation in liver and WAT and suppressed lipogenesis in liver, WAT, and muscle.

In the current study, it was reported that the means of size of tumor among the experimentalgroups revealed that the least mean was in GV $(0.24 \pm 0.03)$ followed byG IV $(0.45 \pm 0.08)$ and thenG III $(0.47 \pm 0.09)$. However, the highest mean was in G II (1.24 \pm 0.18$)$.which explained as normal cells respond to external stimuli by different tightly regulated pathways. However physiology is altered in cancer cells, leading toexcessive growth and reduced cell death. The loss of growth regulation has been attributed to the mutation of oncogenes and tumor suppressor genes. Besides, reduction in the response to cell death stimuli is correlated to aberrant anti-death and pro-death protein expression $^{[45]}$.

Our present findings are supported by Osman et al., 2015 ${ }^{[29]}$ whoreported that Cisplatin treatment in a dose of $(4.5 \mathrm{mg} / \mathrm{kg}$, i.p.) showed marked inhibition of tumor growth.

On the other hand, in Yeast-treated tumor, a tumor growth curve showed a significant suppression of tumor growth by up to $55 \%,(p \leq 0.01)$. Yeast exerts its anti-cancer activity via two independent mechanisms: (1) the apoptotic effect and (2) the immune-modulatory ${ }^{[13]}$.

In the present study, the count of $\mathrm{RBCs} / \mu \mathrm{l}$ showed that the highest mean was recorded in $\mathrm{G}$ Ifollowed byG IV,G IIthen G V. However, the lowest mean was recorded inG III. These findings were of statistically significant $(P \leq 0.05)$.

Comparison between studied groups as regards WBCs number showed that the highest mean was recorded in $G$ V followed by G IV,G II then G III. However, the lowest mean was recorded in $\mathrm{G}$ I. These findings were statistically significant $(P \leq 0.05)$.

These results were concomitant with the study which reported myelosuppression and anemia observed in ascites carcinoma ${ }^{[46]}$. Anemia occurred in ascites carcinoma was due to iron deficiency, either by hemolytic or myelopathic conditions, which finally lead to reduced RBCs count ${ }^{[47]}$.

Prasad et al., (2006) ${ }^{[48]}$ stated that hematological parameters revealed that Cisplatin treatment of mice caused a significant reduction in hemoglobin, RBC, WBCs may indicate the emergence of complications like myelosuppression andthrombocytopenia which are usually associated during cancer chemotherapy.

Anemia observed with Cisplatin use may be caused by a decrease in erythropoietin or erythroid stem cells ${ }^{[49]}$.

\section{CONCLUSION}

In conclusion, heat-killed non-pathogenic yeast enhanced the cytotoxic activity of Cisplatin and potentiates the benefit of using a combination of low-dose Cisplatin and heat-killed non-pathogenic yeast in treatment of cancer.

\section{CONFLICTS OF INTEREST}

There are no conflicts of interest

\section{REFERENCES}

1. Ozaslan M, Karagoz I D, Kilic IH and Guldur ME (2011): Ehrlich ascites carcinoma. African Journal of Biotechnology.10 (13): 2375-2378.

2. Areida SK, Abd El-Azim AO and Amer ME (2015): Protective and Curative Effect of Thymoquinone on Ehrlich Solid Carcinoma Inoculated Mice.The Egyptian Journal of Hospital Medicine (58): 129-142.

3. Sultana S, AsifHM, Nazar HM, et al., (2014):Medicinal plants combating against cancer-a green anticancer approach. Asian Pacific Journal of Cancer Prevention; 15(11):4385-4394.

4. Sana S, Rana S, Rahman S, et al., (2018):. Evaluation of Anticancer Properties against Ehrlich Ascites Carcinoma (EAC) Cell Line, Cytotoxic and Analgesic Activity of Methanol Extract of Hibiscus moscheutos in Swiss Albino Mice Int. J. Pharm. Sci. Rev. Res., 49(2): 128-134.

5. Florea AM, and BüsselbergD (2011):Cisplatin as an Anti-Tumor Drug: Cellular Mechanisms of Activity, Drug Resistance and Induced Side Effects.Cancers (Basel); 3(1): 1351-1371.

6. Ali S, Tahir M, Khan AA, et al., (2019): Cisplatin Synergistically Enhances Antitumor Potency of Conditionally Replicating Adenovirus via p53 Dependent or Independent Pathways in Human Lung Carcinoma Int. J. Mol. Sci. 20, :1-16.

7. Moyad MA (2007): Brewer's/Baker's Yeast (Saccharomyces Cerevisiae) And Preventive Medicine: Complementary and preventive medicine Part I, Urologic nursing; 6 (27):560-561. 
8. Corban $\mathrm{M}$, Ambrose $\mathrm{M}$, Pagnon $\mathrm{J}$ et al., (2019): Pathway Analysis of Fucoidan Activity Using a Yeast Gene Deletion Library Screen. Drugs, 17, 54: $1-15$.

9. Del buono A, Bonucci M, Pugliese S, D'orta A et al., (2016): Polysaccharide from lentinusEdodes for integrative cancer Treatment: Immunomodulatory Effects on lymphocyte population.World Cancer Research Journal ; 3 (1): 652.

10. Kai MP, Keeler AW, Perry JL, et al., (2015): Evaluation of drug loading, pharmacokinetic behavior, and toxicity of a cisplatin containing hydrogel nanoparticle.J Control Release; 204: 70-77.

11. GhoneumM ,Badr El-Din NK, Mahmoud AZ et al.,(2019):Dietary baker's yeast sensitizes Ehrlich mammary adenocarcinoma to paclitaxel in mice bearing tumor ONCOLOGY REPORTS 41: 3155-3166.

12. Elbialy N Sand Mady M M, (2015):Ehrlich tumor inhibition using doxorubicin containing liposomes Saudi Pharmaceutical Journal;2 (23): 182-187.

13. Ghoneum M, Badr El-Din NK, NoamanE, TolentinoL (2008): Saccharomyces cerevisiae, the Baker's Yeast, suppressesthe growth of Ehrlich carcinoma-bearing mice Cancer ImmunolImmunother; 57:581-592.

14. Suvarna K, Layton C and Bancroft J(2018): Bancroft's Theory and Practice of Histological Techniques $8^{\text {th }}$ Edition, Elsevier: 1- 672.

15. Annemarie K, Leonard $M$ and Sharon Stack (2018): Methods in Extracellular Matrix Biology, ScienceDirect: 2-446.

16. Mohamed M A et al.,(2018): An analysis of Bcl2 and Bax markers expression in polymorphous low-grade adenocarcinoma and epithelialmyoepithelial carcinoma of salivary gland, Tanta Dental Journal 2(15): 99-104.

17. Elswefy S E et al.,(2016): Inflammation, oxidative stress and apoptosis cascade implications in bisphenol A-induced liver fibrosis in male rats, Int J Exp Pathol.; 97(5): 369-379.

18. Xiao $\mathrm{N}$ et al., (2019): Improved delivery of doxorubicin by altering the tumor microenvironment using ultrasound combined with microbubbles and chemotherapy.J BUON.;24(2): 844-852.

19. Teixeira AS1, Araújo FA, Ferreira MA, et al., (2006): Angiogenesis and inflammation in skeletal muscle in response to ascites tumor in mice. fe Sci.; 78(14):1637-1645.

20. Frajacomo FT, PadilhaCD, Marinello PC, et al., (2016): Solid Ehrlich carcinoma reproduces functional and biological characteristics of cancer cachexia Life Sciences 162: 47-53.

21. Abdel-Gawada AI, HassanaA. Awwad S A (2016): Efficiency of calcium phosphate composite nanoparticles in targeting Ehrlich carcinoma cells transplanted in mice. Journal of Advanced Research, $1 \mathrm{n}$ (7): 1 143-154

22. Fecchio D, Sirois $P$, Russo $M$, and JancarS (1990): Studies on inflammatory response induced by ehrlich tumor in mice peritoneal cavity. Inflammation, 1 (14): 125-132.

23. Chen L, Deng H, CuiH, et al.,(2018): Inflammatory responses and inflammation-associated diseases in organs Oncotarget; 9(6): 7204-7218.

24. Salem ML, ShoukryNM, Teleb WK, et al., (2016): In vitro and in vivo antitumor effects of the Egyptian scorpion Androctonusamoreuxi venom in an Ehrlich ascites tumor model. Springerplus; 5: 570.

25. Ji H, Cao R, Yang Y, et al., (2014): TNFR1 mediates TNF-alpha-induced tumourlymphangiogenesis and metastasis by modulating VEGF-C-VEGFR3 signalling. Nat Commun. 2014; 5:4944.

26. Hong H, Jiang L, Lin Y, et al. (2016): TNF-alpha promotes lymphangiogenesis and lymphatic metastasis of gallbladder cancer through the ERK1/2/AP-1/VEGF-D pathway. BMC Cancer; $16: 240$

27. Song G, OuyangG,Bao S.(2005): The activation of Akt/PKB signaling pathway and cell survival. J. Cell. Mol. Med.; 9:59-71.

28. Nieto Y (2003):DNA-binding agents. Cancer Chemotherapy \& Biological Response Modifiers; 21:Chapter 8..

29. Osman A , Alqahtani A, Damanhouri Z A, et al., (2015):Dimethylsulfoxideexcerbatescisplatin-induced cytotoxicity in Ehrlich ascites carcinoma cells Cancer Cell Int. 15: 104.

30. Pelizon AC, Kaneno R, Soares AM, et al., (2005): Immunomodulatory activities associated with beta-glucanderivedfrom Saccharomyces cerevisiae. Physiol Res. 54(5):557-564.

31. Bae SH, Park YJ, Park JB, et al., (2007): Therapeutic synergy of human papillomavirus E7 subunit vaccines plus cisplatin in an animal tumor model: causal involvement of increased sensitivity of cisplatintreated tumors to CTL-mediated killing in therapeutic synergy. Clin Cancer Res 13(1):341-349.

32. Spliethoff J W, EversD J, JaspersJ E. et al., (2014): Monitoring of Tumor ResponseUsing Optical Spectroscopy. Elsever.Translational Oncology (7), 2, 2014,: 230-239.

33. Pal S, Choudhuri T, Chattopadhyay S, Bhattacharya A et al.,(2001):Mechanisms of curcumin-induced apoptosis of Ehrlich's ascites carcinoma cells. BIOLOGIJA. Vol. 2; 288(3): 658-65. 
34. Agnieszk, P.; Zbigniew, B.; Marcin, W.; et al. (2005): ultrastructure and immunohistochimical evaluation of apoptosis in foetal rat liver after adriamycin administration. Bull Vet. Inst. Pulawy., 49: $475-448$.

35. Kim, W.H.; Lee, J.W.; Suh, Y.H. ,et al., (2005): exposure to chronic highglucose induces (beta) cell apoptosis through decreased inter action ofglucokinase with mitochondria: down regulation of glucokinaseinbanchriatic beta cells. Diabetes. 54: 2602-2611.

36. Tsamandas, A.C., Thomopoulos, K.,Zolota, V., et al., (2003): potential role of BCL2 and BAX m RNA and protein expression in chronic heapatitis $\mathrm{B}$ and C: Aclinicobiologic study. Mod.Pathol. 16: 1273-1288.

37. Floros $\mathrm{K} \mathrm{V}$,Thomadaki H,Lallas $\mathrm{G}$ et al., (2003): Cisplatin-Induced Apoptosis in HL-60 Human Promyelocytic Leukemia Cells AANALS; 1 (1010) : 153-158.

38. Elwakkad A, GhoneumM , El-sawi E, Mohamed SI, et al., (2018): Baker's yeast induces apoptotic effects andhistopathological changes on skin tumors in mice Cogent Medicine 1(5): 1437673.

39. Sosman JA, Puzanov I. (2006): Molecular targets in melanoma from angiogenesis to apoptosis.Clin Cancer Res. 12(7 Pt 2): 2376s-2383s

40. Rubin H, (2003): Cancer cachexia: Its correlations and causes, Life Sciences Addition, University of California, Berkeley, , 100 (9) 5384-5389.

41. Palkwill, F. R., Mantovani, A. (2012). Cancer-related inflammation: common themes and therapeutic opportunities. Semin. Cancer Biol. 22(1), 33-40.

42. Powers, S. K., Morton, A. B., Ahn, B., Smuder, A. J. (2016): Redox control of skeletal muscle atrophy. Free Radic. Biol. Med.(98),: 208-217.

43. Fearon, K., Arends, J., Baracos, V. (2013): Understanding the mechanisms and treatment options in cancer cachexia. Nature Reviews Clinical Oncology, 10(2), 90-99.

44. Garcia J M, Scherer T, Chen J, et al., (2013):Inhibition of Cisplatin-Induced Lipid Catabolism and Weight Loss by Ghrelin in Male Mice.;Endocrinology 154 (9): 3118-3129.

45. Ortega AL, Mena S and Estrela JM(2011):Glutathione in Cancer Cell Death.cancers, 3:1285-1310.

46. Hashem MA, Mohammed HM, Magda SH (2004): Clinicopathological, pathological and biophysical studies on the effect of electromagnetic field on the Ehrlich tumor cells implanted in mice. Egypt J Comp ClinPathol. 2004;17(2):117-147.

47. Sreelatha S1, Jeyachitra A, Padma PR.(2011):Antiproliferation and induction of apoptosis byMoringaoleifera leaf extract on human cancer cells. Food ChemToxicol. Jun; 49(6):1270-1275.

48. Prasad S. B, Rosangkima G. and Khynriam D. (2006): Cisplatin-induced Toxicological Effects in Relation to the Endogenous Tissue Glutathione Level in Tumor-Bearing Mice Asian J. Exp. Sci., 1 (20), :55-68.

49. McEvoy GK, (2004):Drug Information. Bethesda, Maryland: American Society of Health-System Pharmacists,(3):658-65. 
الملخص العربى

\title{
التأثير التآزري للخميرة والسيسبلاتين ضد السرطان المستحدث في

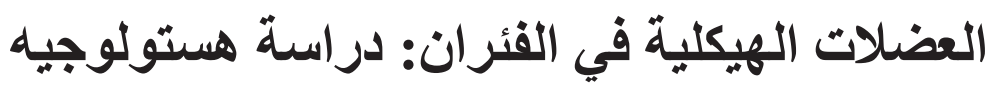

\author{
حكت عبد الموجود أحمد سرور، ايمان سعيد محمود، شيماء زكريا اسماعيل الشوري \\ قسم الهستولوجيا ـ كلية طب (بنات) الازهر- القاهرة - مصر
}

يعتبر السرطان تهديدًا كبيرًا للبشر بين جميع الأمر اض الثائعة في العالم. فهو يعتبر السبب الرئبسي للزيادات في معدل الوفيات عن السنو ات الماضية. على الرغم من أن العلاجات المضادة للسرطان في كل من العلاج الكيميائي و العلاج الإشعاعي سامة، مثبطة للمناعة، ومسببة للطفر ات المؤدية للسرطان مما أدى للحد من فعاليتها كعو امل مضادة للسرطان. يستخدم السيسبلاتين على نطاق واسع لعلاج السرطان إما بمفرده أو بالاشتر الك مع عقار ات أخرى. ومع ذللك، فإن استخداماتها الطبية محدودة بسبب آثار ها الضارة بما في ذللك السمية الكلوية. أو سمية الكلى أو نخاع العظم. العلاج بالأعشاب هو أفضل بديل لعلاج السرطان وتجنب مجموعة متنوعة من الآثار الجانبية الجسدية الناجمة عن بن العلاج الكيميائي والعلاج الإشعاعي. يمكن لهذا العلاج أن يتجنب بنجاح إتلاف الخلايا الطبيعية السليمة الموجودة بالقرب من الخلايا السرطانية. تعتبر الخميرة عامل آمن وغير سام حيث أنها تحتوي على تركيز جيد من البروتين وكذلك معظم الفيتامينات المعقدة ب، باستثناء فيتامين ب r ا وكذللك تحتوي على بيتا جلوكان التي استخدمت كعلاج مساعد لعلاج السرطان في التجارب العملية، مع تأثثر إيجابي على المرضى. تم تقسيم خمسين فئر ان سويسرية من الذكور البيض، إلى خمس مجمو عات، عشرة فئر ان في كل مجموعة. المجمو عة الأولي مجموعة ضابطة. تم حقن بقية الحيوانات عن طريق العضل مع r ب. مل من خلايا إرليخ استسقاء سرطان (0. × > + ( خلايا) في الفخذ الأيمن من الطرف السفلي في اليوم الأول. في غضون عشرة أيام، تحملت الفئران كتلة

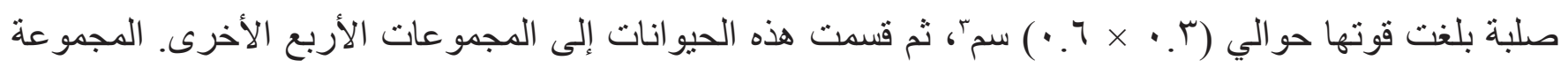
الثانية: بقيت الحيو انات دون علاج واعتبرت "مجموعة ضابطه إيجابية". المجموعة الثالثة:عولجت بالسيسبلاتين بجر عة منخفضة (ب مج / كم من وزن الجسم في الأسبوع) داخل البريتون 'كل يوم اثنين من اليوم الحادي عثر لتلقيح

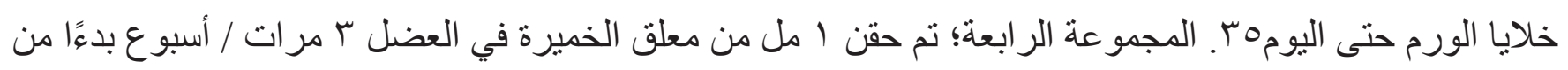
اليوم الحادي عشر لتلقيح خلايا الورم حتى يوم هب. المجموعة الخامسة :تم حقن المل من معلق الخميرة ب مرات في الأسبوع، وكذلك حقن السيسبلاتين بنفس الجر عة السابقة. أجريت در اسة نسيجية للمجموعات التجريبية باستخدام الصبغات المناسبة. أجريت كذاللك در اسات إحصائية ودر اسات مجهريه إلكترونية. كانت التغير ات النسيجية في المجمو عة الثانية تتمثل في شكل ألياف عضلية أصبحت أكثر نحافة وتشوّهًا وفصلت عن بعضها البعض وتسللت إليها خلايا كريات الدم البيضاء أحادية النواة. وتجمعت الخلايا السرطانية متعددة الأشكال و الأحجام وظهر عدد من الانقسامات الميتوزية الغير طبيعية. ألياف العضلات في المجموعة الثالثة ظهرت مجزأة 
و ونفصلة على نطاق واسع عن بعضها البعض، ووجدت بها علامات نخر ولكن الخلايا السرطانية التي تسللت الأنسجة

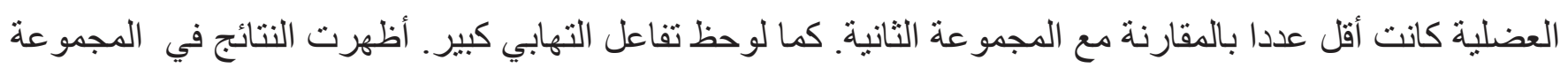
الرابعة والخامسة تحسنا في الصور النسيجية لألياف العضلات. كانت الخلايا السرطانية التي تسللت إلى النسيج العضلي أقل نسبيًا بالمقارنة مع المجمو عة الثانية. استعادت ألباف العضلات مظهرها الطبيعي لتكون مماثلة إلى حد ما لتلك الموجودة في المجموعة الضابطة. نم تأكيد هذه النتائج أيضًا من خلال النتائج المهجرية المناعيّة النسيجيّة و المورمومثرية و الإحصائية.

الخلاصة: عززت الخمبرة غير المسبية للأمراض التي تم قتلها بالحرارة، النشاط السام للسيسبلاتين في الخلايا و عززت فائدة استخدام مزيج من جر عة منخفضة من السيسبلاتين و الخميرة غير المسببة للأمر اض في علاج السرطان. التوصيات:

I ـ من المستحسن أن تأخذ الخميرة كعلاج مساعد للحماية و العلاج من السرطان ץ- إضافة الخميرة إلى طعامنا لأنها تحتوي على تركيز جيد من البروتين وكذللك معظم الفيتامينات المعقدة ب، وكذلك تحتوي على جلوكان بيتا التي تعتبر أنها إنتاج صيانة مناعية. 